\title{
CULTIVATION OF OYSTER MUSHROOM (PLEUROTUS OSTREATUS) ON SAWDUST
}

\author{
L. Pathmashini ${ }^{1 *}$, V. Arulnandhy ${ }^{2}$ and R.S. Wilson Wijeratnam ${ }^{3}$ \\ ${ }^{1}$ Department of Agricultural Engineering, Faculty of Agriculture, Eastern University, Sri Lanka \\ ${ }^{2}$ Department of Agricultural Biology, Faculty of Agriculture, Eastern University, Sri Lanka \\ ${ }^{3}$ Food Technology Division, Industrial Technology Institute (ITI), Colombo 7, Sri Lanka \\ Accepted 25 November 2008
}

\begin{abstract}
A study was conducted to examine the effect of different types of spawns on oyster mushroom (Pleurotus ostreatus) production using sawdust. Locally available grains of kurakkan (Eleusine coracana), maize (broken) (Zea mays), sorghum (Sorghum bicolor), and paddy (Oryza sativa) were used for spawn production. Sawdust spawned with different types $P$. ostreatus spawns were examined for spawn running (mycelia development), pinhead formation and fruit body formation, mean yield, and biological efficiency. The experiment was setup as a complete randomized design with three replicates. The kurakkan spawn produced an acceleration of spawn running, pinhead formation, fruit body formation and increased yield, compared with other types of spawn viz.; maize, sorghum, and paddy. The fastest spawn running of $21 \pm 1$ days, pinhead formation of $35 \pm 1$ days, highest mean yield of $55.37 \pm 0.67 \mathrm{~g}$ and maximum fresh mushroom yield percentage of $30.76 \pm 0.01$ were realized for kurakkan spawn.
\end{abstract}

Key words: Eleusine coracana, Pleurotus ostreatus, Sorghum bicolor, Oryza sativa, Zea mays, spawn

\section{INTRODUCTION}

Oyster mushroom (Pleurotus spp.) cultivation has increased tremendously throughout the world during the last few decades (Chang, 1999; Royse, 2002). Oyster mushroom accounted for $14.2 \%$ of the total world production of edible mushroom in 1997 (Chang, 1999). Oyster mushroom cultivation can play an important role in managing organic wastes whose disposal has become a problem (Das and Mukherjee, 2007). Oyster mushroom can be cultivated in any type of ligno cellulose material like straw, sawdust, rice hull, etc. Hami (1990) studied the oyster mushroom cultivation on sawdust of different woods and found that P.ostreatus gave the maximum yield. Presently sawdust is commonly used and is the preferred medium at commercial scale. Hami (1990) reported that P.ostreatus gave maximum biological efficiency on sawdust. Of the sawdust types, softwood sawdust like mango and cashew are known to be more suitable than hardwood sawdust.

Malnutrition is a problem in developing third world countries. Mushrooms with their flavour, texture, nutritional value and high productivity per unit area have been identified as an excellent food source to alleviate malnutrition in developing countries (Eswaran and Ramabadran,
2000). Among the reasons for the quick acceptance of mushroom is its nutritive content. Mushrooms are eaten as meat substitutes and flavouring. In general edible mushrooms are low in fat and calories, rich in vitamin $\mathrm{B}$ and $\mathrm{C}$, contain more protein than any other food of plant origin and are also a good source of mineral nutrients (Bahl, 1998).

Currently, high biofuel prices have caused an increase in food prices and food scarcity in many countries (World Bank, 2008). To alleviate hunger and malnutrition in a world of rising food prices, cultivation of mushrooms is a very reliable and profitable option.

The objectives of this study were to evaluate selected grain media for spawn production and find out the most suitable media for spawn production.

\section{MATERIALS AND METHODS}

\section{Location}

The spawn production was carried out at the Industrial Technology Institute (ITI), Colombo. Experiments were carried out in a pre built mushroom hut at the Faculty of Agriculture, Eastern University.

*Corresponding author's email: littlepathu@yahoo.com 


\section{Stock pure cultures}

Stock pure culture of $P$. ostreatus obtained from Industrial Technology Institute (ITI), Colombo was maintained on Potato Dextrose Agar (PDA).

\section{Spawn production}

The grains, kurakkan, maize, sorghum and paddy were cleaned manually to remove inert matter, stubble and debris. The cleaned grains were soaked in $0.5 \% \mathrm{CuSO}_{4}$ for $10 \mathrm{~min}$ and the soaked grains were thoroughly washed and soaked in tap water for 2 hours. Thereafter, the soaked grains were drained and the excess water removed and the following additives added. Rice bran at the rate of $10 \%$, chalk $\left(\mathrm{CaCO}_{3}\right)$ at the rate of $2 \%$, and epsom $\left(\mathrm{MgSO}_{4}\right)$ at the rate of $0.2 \%$ on dry weight basis of the grains. The additives were thoroughly and evenly mixed with the grains. The grain medium was filled in to polypropylene bags (200 gauges, $37.5 \mathrm{~cm}$ long, and $17.5 \mathrm{~cm}$ wide). About $200 \mathrm{~g}$ of medium was packed in each bag. The bags were sealed using cotton wool plugged conduit/ poly vinyl chloride pipe rings, and covered by a piece of paper by tying a rubber band around the neck. The bags were autoclaved at $121^{\circ} \mathrm{C}, 15 \mathrm{psi}$, for $30 \mathrm{~min}$ and the sterilized bags were allowed to cool for 24 hours. The bags were immediately inoculated with mycelial culture of $P$. ostreatus maintained on PDA.

\section{Media preparation}

A medium was prepared using sawdust of mango, rice bran (at the rate of $10 \%$ ), chalk (at the rate of $2 \%$ ), and epsom (at the rate of $0.2 \%$ ) on the dry weight basis of the substrate and were mixed thoroughly with water. The correct water content was checked by pressing the medium by hand. The medium was filled into polypropylene bags. About $800 \mathrm{~g}$ of medium was packed into each bag.

The bags were then sealed, autoclaved and inoculated with the four types of spawn sorghum (T1), kurakkan (T2), maize (T3), and paddy (T4). Sawdust substrate in bags were inoculated with approximately $2 \mathrm{~g}$ of spawn using surface spawning technique under laminar flow and incubated in a dark chamber.

\section{Determination of spawn run}

The growth of mycelium (linear length) in each bag was measured by a measuring tape at 6 day intervals. Using this data, spawn run rate (cm/day) was determined for every spawn type. When the mycelium fully covered the substrate bag (spawn run completed), bags were kept open in the growing house. The days required for the completion of spawn running in the substrate bag were recorded. Days for pinhead formation, fruit body (flush) formation and for harvest was recorded.

\section{Mushroom yield}

Total mushroom yield (five flushes) was expressed as accumulated fresh weight of mushrooms and as the accumulated biological efficiency (BE), i.e. accumulated fresh weight of mushrooms expressed on the basis of dry weight of initial substrate.

\section{Experimental design}

In the experiments complete randomized design with three replicates and four types of spawn were tested viz., paddy spawn, maize (broken) spawn, sorghum spawn, and kurakkan spawn.

\section{Data analysis}

Data were analyzed using the analysis of variance (ANOVA) procedure by SAS and means were separated using Duncan's Multiple Range Test (DMRT) at $\mathrm{p}=5 \%$.

\section{RESULTS}

Kurakkan spawn (T2) showed a faster rate of mycelium growth (Fig. 1) during the spawn run. Paddy spawn showed a markedly slow rate of mycelium growth in relation to all other spawn types. Kurakkan spawn (T2) showed the highest rate of spawn run of $0.827 \mathrm{~cm} /$ day, while it was $0.797,0.763$, and $0.524 \mathrm{~cm} /$ day for maize (T3), for sorghum (T1) and paddy (T4), respectively.

There were significant differences in the days taken for completion of spawn run between paddy spawn and others viz., sorghum, kurakkan, and broken maize (Table 1). Paddy spawn was significantly different from the other three types of spawn in taking the longest period of $32 \pm 2$ days for the completion of spawn run (Table 1). Sorghum, kurakkan, and broken maize took $23 \pm 1,21 \pm 1$, and $22 \pm 1$ days for the completion of spawn run respectively. Days for pinhead formation was longest in paddy spawn (50 \pm 1 days), while sorghum, kurakkan, and broken maize took $36 \pm 1,35 \pm 1$, and $45 \pm$ 1 days for pinhead formation, respectively (Fig. 2).

Time taken for the first flush, was also longest in paddy spawn (43 \pm 1 days) while 
sorghum, kurakkan, and broken maize took $32 \pm$ $1,31 \pm 1$, and $38 \pm 1$ days, respectively.

Total mushroom yield differed significantly among the four types of grain spawns tested (Table 2). Highest fresh weight (yield) of 276.87 $\pm 0.30 \mathrm{~g}$ was obtained with kurakkan spawn (T2) followed by sorghum (T1), maize (T3), and paddy (T4) of $228.45 \pm 0.29,149.15 \pm 0.30$, and $107.87 \pm 0.30 \mathrm{~g}$, respectively. There were significant differences in the mean biological efficiency (BE) of five harvests among the four different spawn types (Table 2) with maize and paddy having similar efficiency.

Highest BE was recorded for the harvests obtained from kurakkan spawn $(30.76 \pm 0.01)$ which significantly differed from that of the other three spawn types. Sorghum recorded the second highest $(25.38 \pm 0.05)$ for $\mathrm{BE}$, which significantly differed from $\mathrm{BE}$ of maize and paddy spawns.

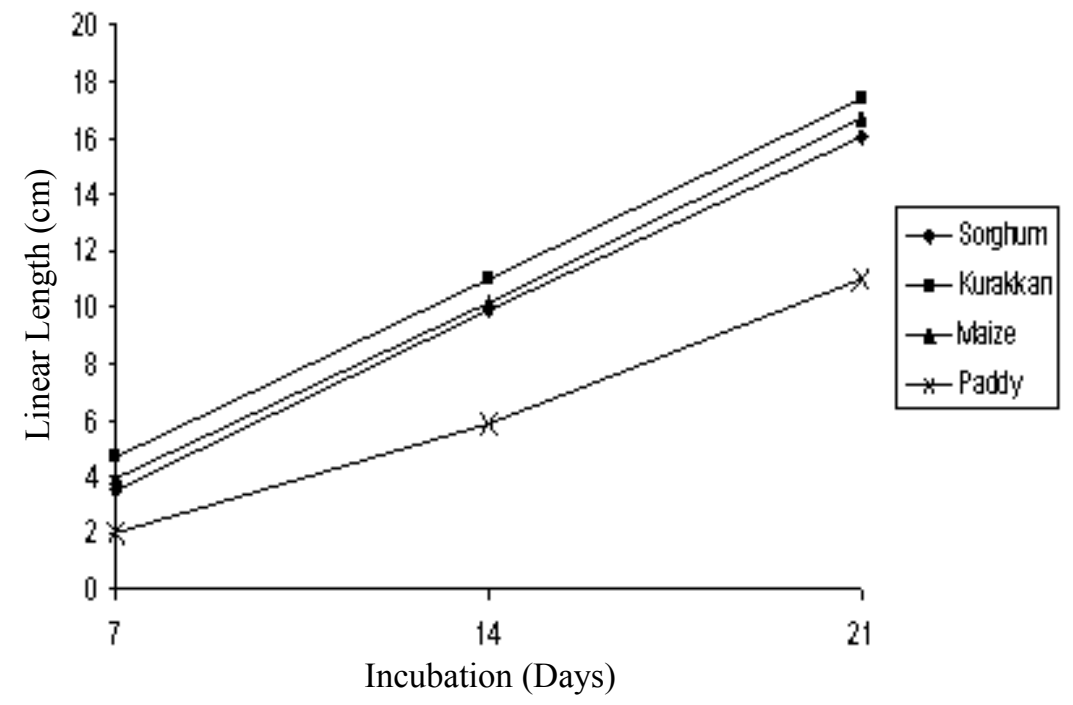

Figure 1. Time course of spawn running using different spawn types to inoculate sawdust based substrate.

Table 1. Spawn Run: Length of mycelia over time.

\begin{tabular}{llrl}
\hline Spawn Type & \multicolumn{3}{c}{ Spawn Run $(\mathbf{c m})$} \\
\cline { 2 - 4 } & $\mathbf{7}^{\text {th }}$ Day & $\mathbf{1 4}^{\text {th }}$ Day & $\mathbf{2 1}^{\text {st }}$ day \\
\cline { 2 - 4 } Sorghum (T1) & $3.533 \pm 0.257^{\mathrm{b}}$ & $9.875 \pm 0.760^{\mathrm{a}}$ & $16.033 \pm 0.601^{\mathrm{b}}$ \\
Kurakkan (T2) $^{\mathrm{a}}$ & $4.667 \pm 0.629^{\mathrm{a}}$ & $11.014 \pm 1.658^{\mathrm{a}}$ & $17.375 \pm 0.705^{\mathrm{a}}$ \\
Maize (T3) $^{\mathrm{a}}$ & $3.95 \pm 0.180^{\mathrm{ab}}$ & $10.142 \pm 0.302^{\mathrm{a}}$ & $16.75 \pm 0.661^{\mathrm{ab}}$ \\
Paddy (T4) & $2.00 \pm 0.508^{\mathrm{c}}$ & $5.902 \pm 0.806^{\mathrm{b}}$ & $11.00 \pm 0.500^{\mathrm{c}}$ \\
\hline Values followed by the same letter in a row are not significantly different at $\mathrm{p}=0.05-$ DMRT.
\end{tabular}

Values followed by the same letter in a row are not significantly different at $\mathrm{p}=0.05-$ DMRT. 


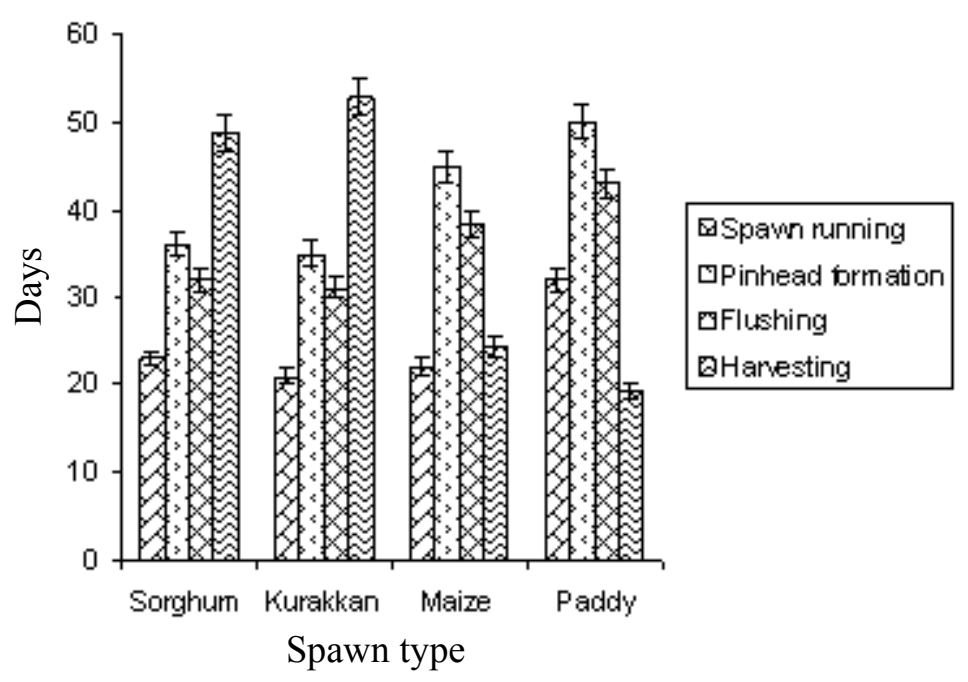

Figure 2. Days for spawn running, pinhead formation, flushing and harvesting of different spawn types.

Table 2. Interaction of spawn types on sawdust.

\begin{tabular}{|c|c|c|c|c|}
\hline \multirow{2}{*}{$\begin{array}{l}\text { Time in days } \\
(\text { Mean } \pm \text { SD) }\end{array}$} & \multicolumn{4}{|c|}{$\begin{array}{c}\text { Spawn Types } \\
\end{array}$} \\
\hline & Sorghum (T1) & Kurakkan (T2) & Maize (T3) & Paddy (T4) \\
\hline Spawn run & $23 \pm 1^{b}$ & $21 \pm 1^{b}$ & $22 \pm 1^{b}$ & $32 \pm 2^{a}$ \\
\hline Pinhead & $36 \pm 1^{\mathrm{c}}$ & $35 \pm 1^{c}$ & $45 \pm 1^{b}$ & $50 \pm 1^{a}$ \\
\hline Flush & $32 \pm 1^{\mathrm{c}}$ & $31 \pm 1^{\mathrm{c}}$ & $38.33 \pm 1^{\mathrm{b}}$ & $43 \pm 1^{\mathrm{a}}$ \\
\hline Harvest & $48.85 \pm 0.67^{b}$ & $52.94 \pm 0.67^{\mathrm{a}}$ & $24.35 \pm 1.37^{\mathrm{c}}$ & $19.37 \pm 1.58^{\mathrm{d}}$ \\
\hline Total Yield ${ }^{\top}(\mathrm{g})$ & $228.45 \pm 0.29^{b}$ & $276.87 \pm 0.30^{\mathrm{a}}$ & $149.15 \pm 0.30^{\mathrm{c}}$ & $107.87 \pm 0.30^{d}$ \\
\hline Mean Yield* $(g)$ & $45.69 \pm 0.67^{b}$ & $55.37 \pm 0.67^{\mathrm{a}}$ & $29.83 \pm 1.37^{\mathrm{c}}$ & $21.57 \pm 0.37^{\mathrm{d}}$ \\
\hline $\mathrm{BE} \%+$ & $25.38 \pm 0.05^{b}$ & $30.76 \pm 0.01^{\mathrm{a}}$ & $16.57 \pm 0.67^{\mathrm{c}}$ & $11.99 \pm 0.67^{\mathrm{c}}$ \\
\hline
\end{tabular}

Total fresh weight of five harvests.

${ }^{*}$ Mean yield of five harvests.

+ Accumulated $\mathrm{BE} \%$, the ratio of fresh mushroom harvested/ initial dry weight of substrate expressed as a percentage.

Values followed by different letters in a row differ significantly at $\mathrm{p}=0.05$ based on DMRT.

\section{DISCUSSION}

The days taken for the completion of spawn run except for paddy spawn, were in agreement with the findings reported by Shah et al. (2004) and Tan (1981) where the spawn run took three weeks.

Variations in spawn run rate may be attributed to the size of the grains. Smaller grains have a greater number of inoculation points per $\mathrm{kg}$ than larger grains (Mamiro and Royse, 2008). It was found that the spawn run rate of smaller grains was higher than the larger grains. However, larger grains have a greater food reserve (Elliot, 1985) and can sustain the mycelium for longer periods of time during stress (Fritsche, 1988). Thus, different types of spawn may influence productivity and growth.
The findings of the spawn run did not agree with those of Ahmed (1986) who stated that $P$. ostreatus completed the spawn run in $17-20$ days and pinheads formation in $23-27$ days. Shah et al. (2004) reported 24 days for pinheads formation on sawdust medium. The days for pinhead formation and days for flush (fruiting bodies) formation recorded in this study were longer than previous findings. This may probably be associated with the temperature and humidity. Study by Shah et al. (2004) was conducted at $25^{\circ} \mathrm{C}$ where spawn running and pinhead formation were observed. Quimo (1976, 1978) too reported that fruiting bodies appear 3 -4 weeks after inoculation of spawn while Shah et al. (2004) stated that pinheads appear $27-34$ days after inoculation at $17-20^{\circ} \mathrm{C}$.

This finding on the yield contrasted with the results of Shah et al. (2004) and seems relatively 
low compared to commercial production and was probably associated with the substrate (sawdust). Shah et al. (2004) recorded maximum yield of $646.9 \mathrm{~g}$ for three harvests through a different cultivation technique. Shah et al. (2004) adopted fermentation of substrates (sawdust) for five days to boost the yield and the temperature was maintained at $17-20^{\circ} \mathrm{C}$ throughout the period of fructification (flush forming). Bano and Srivastava (1962) recorded a yield of $22 \mathrm{~g}$ of total fresh weight.

Arulnandhy and Gayathri (2007) obtained a mean yield of $24 \mathrm{~g}$ on sawdust medium while Obodai and Vowotor (2002) obtained a mean yield of $25.5 \mathrm{~g}$. Compared to these findings we obtained higher mean yields for sorghum (45.69 g), kurakkan (55.37 g) and maize (29.83 g) and comparable yield for paddy (21.57 g) spawns.

Bano and Srivastava (1962) obtained a mean yield of $60 \mathrm{~g}$ by using sawdust and straw in the ratio of $1: 1$, while Arulnandhy and Gayathri (2007) obtained $55 \mathrm{~g}$ using the same substrate composition. When sawdust was incorporated with dry leaves Arulnandhy and Gayathri (2007) obtained a mean yield of $22 \mathrm{~g}$ and with shredded paper a mean yield of $47 \mathrm{~g}$. Sawdust incorporated with substrates like straw and grasses (Udugama and Ranjani, 1997), shredded paper (Arulnandhy and Gayathri, 2007) enhanced the yield rather than sawdust alone.

\section{CONCLUSION}

Kurakkan spawn showed the highest rate of spawn run of $0.827 \mathrm{~cm} /$ day. Kurakkan spawn was found to be the most efficient spawn type for growth in the sawdust medium compared to other spawns tested. Paddy spawn took significantly longer time for spawn running, flush formation, and days for harvest. Kurakkan spawn produced the highest mean yield of 55.37 $\pm 0.30 \mathrm{~g}$ and fresh mushroom yield percentage of $30.76 \pm 0.01$. Thus kurakkan is the best spawn type among the four spawn types tested.

\section{ACKNOWLEDGEMENTS}

We express our sincere gratitude to the World Bank funded IRQUE project for providing funds for this study.

\section{REFERENCES}

Ahmed, I. (1986). Some studies on oyster mushroom (Pleurotus spp.) on waste material for corn industry. M.Sc. Thesis, University of Agriculture, Faisalabad, Pakistan. Pp. 25 - 50.

Annonymous. World Bank Report. High Food Prices - A Harsh New Reality. Retrieved on www.econ.worldbank.org as on 7/15/2008.

Arulnandhy, V. and Gayathri, T. (2007). Identification of suitable and efficient substrate for the production of oyster (Pleurotus ostreatus) mushrooms. Undergraduate research report, Department of Agricultural Biology, Faculty of Agriculture, Eastern University, Sri Lanka.

Bahl, N. (1998). Hand book on mushrooms. Oxford \& IBH Publishing co Pvt Ltd. Pp.15-40.

Bano, Z. and Srivastava., H.C. (1962). Studies on the cultivation of Pleurotus species on paddy straw. Food Science 11(12): 363 - 365.

Chang, S.T. (1999). World production of cultivated and medicinal mushrooms in 1997 with emphasis on Lentinus edodes. International Journal of Medicinal Mushrooms. 1: 291 - 300.

Das, N. and Mukherjee, M. (2007). Cultivation of Pleurotus ostreatus on weed plants. BioResource Technology 98: 2723 - 2726. www.science direct.com retrieved on 07/08/2007.

Elliot, T.J. (1985). Spawn - making and Spawns. In: The Biology and Technology of the Cultivated Mushrooms, P.B. Flegg, D.M. Spencer and D.A. Wood (Eds.), John Wiley \& Sons Ltd. Pp. 131- 139.

Eswaran, A. and Ramabadran, R. (2000). Studies on some physiological, cultural and post harvest aspects of oyster mushroom, Pleurotus eous. Tropical Agricultural Research. 12: 360 374.

Fritsche, G. (1988). Spawn: properties and preparation, In: The Cultivation of Mushrooms. van Griensven, L.J.L.D. (Eds.), Darlington Mushroom Laboratories, Sussex. Pp. 1-99.

Hami, H. (1990). Cultivation of oyster mushroom on sawdust of different woods. M.Sc. Thesis, University of Agriculture, Faisalabad, Pakistan. 
Mamiro, D.P. and Royse, D.J. (2008). The influence of spawn type and strain on yield, size and mushroom solids content of Agaricus bisporus produced on non-composted and spent mushroom compost, Bioresource Technology. 99 (8): 3205-3212. www.sciecedirect.com retrieved on $07 / 08 / 2007$.

Obodai, M. and Vowotor, K.A. (2002). Performance of different strains of Pleurotus species under Ghanaian conditions. Journal of Food Technology in Africa. 7 (3): 98-100.

Quimo, T.H. (1976). Cultivation of Ganoderma the Pleurotus-way. Mushroom Newsletter for the Tropics 6: $12-13$.

Quimo, T.H. (1978). Indoor cultivation of Pleurotus ostreatus. Phillipines Agriculturist, 61: $253-262$.
Royse, D.J. (2002). Influence of spawn rate and commercial delayed release of nutrient levels on Pleurotus conocopiae yield, size and time to production. Applied Microbiology and Biotechnology. 17: 191 - 200.

Shah, Z.A., Ashraf, M. and Ishtiaq, M. (2004). Comparative study on cultivation and yield performance of oyster mushroom (Pleurotus ostreatus) on different substrates (wheat straw, leaves, sawdust). Pakistan Journal of Nutrition. 3 (3): $158-160$.

Tan, T.T. (1981). Cotton waste is a fungus (Pleurotus). Good substrate for cultivation of Pleurotus ostreatus the oyster mushroom. Mushroom Science. 11: 705 - 710.

Udugama, S. and Ranjini, S. (1997). Mushroom as an agent of recycling wild grass to an edible food for man. Annual Sessions of the Department of Agriculture (ASDA). 53:8. 